\title{
"WHERE BUTCHERS SING LIKE ANGELS" \\ Of Captive Bodies and Colonized Minds \\ (With a Little Help from Louise Erdrich)
}

The most insidious oppressions are those that so insinuate themselves into the fabric of our lives and into the recess of our minds that we don't even realize they are acting upon us.

(Michael Parenti)
Małgorzata Poks

Guest-Editor

Faculty of Humanities University of Silesia in Katowice Poland

(iD

\section{PROLEGOMENA}

Since 1984, the publication year of her debut novel Love Medicine, Louise Erdrich, an American author of German and Chippewa origin, has been constructing a cycle of interconnected narratives that converge on a North Dakota reservation and the nearby towns, such as Argus. Readers of The Master Butchers Signing Club (2003) are introduced to Argus in the second decade of the $20^{\text {th }}$ century, when it is rapidly expanding thanks to the newly constructed railroad connecting it to the rest of the country. As a town built on unceded aboriginal lands, Argus is symbolic of the white man's victorious war against America's indigenous inhabitants, whose tragic fate is epitomized by the ragpicker Step-and-a-Half, a deeply traumatized survivor of the Wounded Knee Massacre. On the other hand, the town's two thriving butcher shops are telling reminders of the original colonizing project-that of human mastery over animals.

Alien to the hunting cultures of North America's indigenous inhabitants-Step-and-a-Half's ancestors-the domestication and exploitation of large social animals for food and as a workforce has, according to sociologist David Nibert, "engendered large- 
Captive Minds Normativities and Protests

scale violence against and injury to devalued humans, particularly indigenous people around the world." In the final analysis, rather than being the much touted leap in the development of humanity, domestication-more aptly called domesacration-"undermined the development of a just and peaceful world" (Nibert 2). In this article, I will draw on methodologies provided by decolonial thinking and Critical Animal Studies to argue that violence against animals and violence against devalued/animalized humans are two sides of the same coin.

Sociologist Lucy Mayblin succinctly defines the main thrust of decolonial thinking in the following way: "decolonialists seek to draw attention to the relation between colonialism and the narrative of modernity, through which much of the world's history has come to be understood. Modernity, then, is viewed as an epistemological frame that is inseparably bound to the European colonial project" (Mayblin). My article is guided by the same ambition. With the help of Louise Erdrich, a U.S. author of mixed Euro-Cherokee descent, I aim to contest the accepted reading of the modern narrative of progress and foreground the trope of war against the animal(ized) Other I identify in her novel. Being partly indigenous and partly white, Erdrich transfers her divided loyalties onto the written page, revealing fundamental fault lines in modernity's masternarrative. Reading closely carefully chosen fragments of Master Butchers Singing Club, I follow the associative paths suggested by the words and images used by the author. Not arguing explicitly against modernity, Erdrich nevertheless manages to capture much of its "dark side." My article will try to bring this repressed, invisiblized part of the modern narrative into light.

I wish to stress that my article is not a systematic analysis of Erdrich's novel. On the contrary, I wish to use the text as an illustration of the larger thesis, namely, that the ongoing war against the nonhuman and the not-quite-human cannot be properly understood without critiquing the idea of human exceptionalism, a concept unknown to Paleolithic-style small-scale societies, whose members realized they were constituted by their relations with other, nonhuman selves. For them, preserving those relations was essential for the good life. The Western hu/man, 
on the other hand, constituted in the act of separating himself from nature, is a schizophrenic figure, bent on killing the nonhuman Other that in fact, co-constitutes him. ${ }^{1}$ Although capable of utter selflessness and the most astonishing works of beauty, he is not an angel, as evidenced by the long list of modern atrocities committed in the name of white privilege. In the course of my analysis, I will draw on Master Butchers Singing Club to illustrate the schizophrenia of modern life: trying to live the good life as advanced by Western culture, we ${ }^{2}$ perform acts of atrocious violence against the animal(ized) Other, often without realizing it. Socialization into the structures of oppression makes us blind to the violence inherent in our lives. Only a vision from the margin, similar to that granted to Erdrich's Delphine, can reveal what has been occluded by the notions of progress and prosperity. Positing that everybody has been colonized in mind and body in the course of history, ${ }^{3}$ I will conclude by suggesting the need for decolonizing our relations with all living beings. I want to argue that we will never be fully human unless we recover a sense of embeddedness in a web of relations that co-constitute us (Sepie). By allowing an indigenous author to have the last word in this article, I wish to honor the wisdom of traditional worldviews which are not my own and to which, therefore, I have no rightful claim.

THE VIOLENCE OF HUMANISM

David Nibert is part of a growing number of scholars who believe that the anthropological machine (Agamben 33-38)-that is, the philosophical and scientific production of human life as distinct from the life of animals-is at the root of all modern oppressions.

1. The spelling of hu/man-with a slash-is to draw attention to the fact that modern humanity has been defined in explicitly masculine, patriarchal terms. Within this article, I shall be using 'white privilege' and 'normative humanity' as synonyms terms.

2. Erdrich is of indigenous and European descent and often speaks simultaneously from the two epistemologies she has inherited. Thus, the 'we moderns' would also, at least partly, include her. As for myself, being a white European woman, I realize I am part of the 'we' too, having been co-constituted by the same cultural codes I am trying to contest.

3. Although I have been reaching similar conclusions in my previous research, I want to acknowledge Amba J. Sepie as the direct source of this formulation. 
Captive Minds Normativities and Protests

Legal scholar Tarik Kochi of the University of Sussex, for example, demonstrates how decisions about what constitutes 'legitimate' violence are influenced by our assumptions about the value of life. The bare life-especially if it threatens the 'good life' as defined by Western modernity-is believed to be justifiably eliminable. War is a legitimate form of violence against life construed as zoe, or bare, which is commonly associated with purely utilitarian value. Livestock would be a prime example of the bare life-bred for consumption, they are denied any intrinsic worth and have almost no (executable) legal rights. According to Kochi, therefore, "what sits at the foundation of the Law of war is a discourse of species war that over time has been so naturalized within Western legal and political theory that we have almost forgotten about it." Admitting that "species war may not be a Western monopoly," the scholar nevertheless soberly accepts the West's responsibility for imposing its own specific form of species war on the rest of the world through the interconnected processes of colonization and globalization (356). "For most humans in the West," adds Kochi, "the 'good life' involves the daily killing of animals for dietary need and for pleasure" (362). Another legal scholar, Maneesha Deckha from the University of Victoria, draws the inescapable conclusion suggested but not explicitly articulated by Kochi. Finding the subhuman to be "the cultural agent of violence," she concludes that humanism is synonymous with violence. Grounded as it is in oppositional thinking, humanism will always work through the logic of exclusion, the subhuman and non-human situated as the 'legitimate' recipient of violence.

Australian scholar Dinesh Wadiwel is another crucial contributor to the discussion of species war. Although I am in no way capable of doing justice to his profound book The War Against Animals in the space available, it is important to note that the author explicitly uses the trope of war to theorize human-animal relations. Having established his sovereignty over animals, man treats them as spoils of war to secure "the continual excess of human claimed rights and pleasures" (Wadiwel 23). The spoils of war, 
whose intrinsic worth is constructed as negligible, are to enhance the quality of human life-the only life worth consideration.

Yet, how do we move beyond oppositional politics inherent in the discourses of humanism? How do we end species war in a way that would not replicate exclusionary thinking or ensure the perpetration of violence meted out in the name of the good life of the normative human? Decolonial critics point to the necessity of de-linking from the categories of thought imposed by colonialism and globalization and the subsequent retrieval of ancestral wisdoms for 'thinking otherwise.' To think human-animal relations otherwise, in ways repressed by the paradigm of human dominionism, we need to think disobediently. "Epistemic disobedience," argues Walter Mignolo, "is necessary to take on civil disobedience to its point of non-return" ("Epistemic Disobedience" 17).

Another philosopher of decoloniality, Nelson Maldonado-Torres, in his book Against War aptly subtitled Views from the Underside of Modernity, finds violence and war to be more then "contingent results of particular historical projects. "For victims of colonialism violence and war appear as "constitutive dimensions of dominant conceptions of civilization and civilizational progress" (5). Underneath the triumphalist rhetoric of progress hides modernity's dark unconscious, the repository of the repressed crimes of coloniality which made modernity possible. In accordance with the logic of Freudian psychoanalysis, this dark side of modernity continues to inform our daily choices and thus locks us in the prison house of compulsive repetitions of the past. Unless, that is, we dare to question the worldview available from the "zero point" of Western man's epistemic privilege (Castro-Comez, qtd. in Grosfoguel).

Questioning the assumptions we moderns live by implies choosing to position ourselves on the underside of modernity, together with the human and non-human victims of manifold oppressions invisibilized by the progressive paradigm of modernity. A view from the margin is certain to subvert our comforts and little securities, but then again, liberation from mental captivity is meant to be a revolutionary event, requiring a corollary revolutionary change in lifestyle. While a negative peace is simply an absence of tension, and has to be enforced by recourse to legal 
violence, positive peace-the presence of justice-resolves tensions and abolishes hierarchical distinctions.

\section{DELPHINE: A VIEW FROM THE MARGIN}

Delphine Watzka, the main female protagonist of The Master Butchers Singing Club, is of uncertain origin. She believes that her father is a local drunkard of Polish descent, and that her mother, supposedly a Native American, died soon after Delphine was born. All this turns out to be untrue. At the novel's end, the readers learn (but Delphine never does) that her biological mother, a pathological Mrs. Shimek, discarded her as a newborn infant into an outhouse and that the Wounded Knee survivor, Step-and-a Half, rescued the girl and brought her to Roy Watzka's house. As a poor woman, supposedly of native descent, struggling for her and her father's survival and performing as a circus artist with a gay partner with Ojibwe roots, Delphine is multiply marginalized within the patriarchal, assimilationist society of the first half of the $20^{\text {th }}$ century. By marrying the local butcher, Fidelis Waldvogel, she leaves the margin and joins the local elite. From that moment on, Delphine too can participate in the good life advertised as available to all hard-working, conscientious Americans, regardless of their origins.

As both substitute mother to four young men who fight on both sides of the Second World War and her husband's partner in the butchering business, Delphine is no innocent bystander

Captive Minds Normativities and Protests to modernity's wars. Yet, it is she who, at the novel's close, is granted a vision from the underside of modernity. In a particularly lucid moment, she sees beyond the socially constructed ideas and normativities of the Western world. The vision of naked reality is a vision of the world at war. At the unveiling of a monument to the victims of the bombing of Ludwigsruhe, Fidelis's hometown, a choir of master butchers performs in the open. Bewildered by the strange culture and alienated among her husband's Cerman relatives, Delphine experiences a moment of acute derealization. Looking at the festive celebrations, she is reminded of the atrocities that had taken place there a short while before"the burning, the marching, an enormity beyond her, a terrible strangeness in which things unbelievable were done" (375). But now the town is beautiful and orderly again, the gathered audience 
are elegant, cheerful, carefree. For some reason, she sees a photo of the young Step-and-a-Half blur with the scene in front of her. Delphine no longer hears the singing; she only sees "the mouths of the men opening and shutting in unison, in a roar, like some collection of animals in a zoo" (375). The scene continues:

She saw what was really happening. As the veil was torn away, as the statue of the burned stood washed in pleasant sunlight, as the master butchers parted their lips in song, smoke and asn poured out of their mouth holes like chimneys. Their hearts were smoldering, she thought disoriented. Their guts were on fire. Their lungs were hot bellows. Yet they kept on singing as though nothing was wrong at all. Nobody pointed, no children cried. Darkness continued to spiral out of the men's oven-box chests. Smoke swirled, ash drifted. Finally the singing ended. All the cloudy dark the men had belched disintegrated and was gone, except for the tarry residues of the shadows. People surrounding her smiled and nodded. Clapped their hands with a solid racking clatter that went on and on. So, thought Delphine, very tired, throwing her hands together along with everyone else, it was normal for black plumes to rise from the mouths of the singing butchers into the brilliant air of the garden. It was an ordinary thing to witness here. (375-76)

The light and the shadow, the glittering surface and the atrocities buried underneath-the latter invisible yet constitutive of the project of modernity-this is Western culture's schizophrenia laid bare in Delphine's vision. She sees both sides of the modern/colonial coin. A nation that produced some of the (Western) world's greatest poets, philosophers, and musicians produced also the Übermensch, the Superhuman, the Führer-a semi-divine figure existing outside of the rule of law; creator of the modern death camp for those who failed to meet the criteria for inclusion in the race of masters. By superimposing Step-and-a-Half's photo on the surrealist picture of the smoke-belching German butchers singing in a beautiful harmony of voices, Erdrich identifies the violence of colonialism with the beginning of the modern paradigm of war (against the subhuman). In Erdrich's historical intervention, the Wounded Knee Massacre anticipates the Final Solution.

On December 29, 1890, about 300 peaceful Lakota men, women, and children were massacred at a camp the U.S. cavalrymen had ordered them to set up the previous day. Instead of the protection promised by the U.S. army, the weary Indians were liquidated in the prototype of a modern death camp. Literary 
scholar John Carlos Rowe has this to say about the role Wounded Knee plays in The Master Butchers Singing Club: "Like a ghostly return of the repressed in Freudian psychoanalysis, Wounded Knee surfaces several times in Erdrich's novel as the unconscious of Argus, North Dakota, and by extension the entire modernization process of the United States" (169). Normalized and repressed to the shadowy region of the cultural unconscious, genocidal violence is the unacknowledged price for the good life Western style, violence being "an ordinary thing to witness here" (376).

Despite her insight into the heart of modern darkness, Delphine applauds the master butchers' problematic performance "with everyone else." Rather than delink from the violence produced by normative humanity, she passively accepts her participation in its privileges, because she is concerned with assimilation. Delphine is a figure of reconciliation and care in the novel. This is why she helps to run the butcher shop and passively watches Fidelis shoot the feral dogs whom he had previously fed. A victim of the colonial matrix of power herself, Delphine, whose very name suggests affinities with animals, has been socialized to participate in the structural oppression of devalued bodies, to oppress and exploit other damnés. Although she secretly sympathizes with the dogs, hoping some will have escaped Fidelis's rifle, she is not ready to renounce the privileges of her social standing. As a middle-class, decent woman with a liberal conscience, Delphine represses the animal

Captive Minds Normativities and Protests Other, happy to be included in the elite category of the human. Her solidarity with victims of systemic oppressions outside of her family rarely goes beyond charity.

To speak from the margin is to speak in resistance, wrote bell hooks. Only if consciously embraced, however, can the margin become a site of struggle, a site "where transformation is possible" (hooks 203). Hooks asks: "Within complex and ever shifting realms of power relations, do we position ourselves on the side of colonizing mentality? Or do we continue to stand in political resistance with the oppressed?" (203, emphasis added).

\section{FIDELIS: THE NORMATIVE HUMAN}

Newly arrived in the USA, Fidelis Waldvogel, a German immigrant traumatized by World War I, is struggling with the problem 
of identity and cultural assimilation-a master theme of Erdrich's novels. But by settling in Argus, he is also, albeit involuntarily, participating in the ongoing dispossession of native peoples from their ancestral lands and the marginalization of their traditional lifeways. Fidelis is an admirable character of great moral probity, an emblematic modern man: hard-working, persevering, self-made. He is a faithful and protective husband, a loving father, and a man of honor. Yet, to be all of the above, he has to cultivate manifold epistemologies of ignorance ${ }^{4}$ to keep at a safe distance the specter of coloniality's dark side. Not an innocent bystander to direct violence against the Other, Fidelis is modern man par excellence, suppressing doubts of moral nature as prerequisite for achieving the required stance of detached, professional mastery.

As a sniper in the Great War, Fidelis was among the most feared soldiers on the battlefield. Although specially trained marksmen had been used in earlier conflicts, German snipers made history as the first ever to use rifles with telescopic sights, which allowed them to shoot with incredible precision. Moreover, in contrast to British marksmen,

German snipers did not normally work from their own trenches. The main strategy was to creep out at dawn into no-man's land and remain there all day. Wearing camouflaged clothing and using the cover of a fake tree, they waited for a British soldier to pop his head above the parapet." ("Snipers")

The combination of exceptional skills, expert training, and the ability to operate independently of other soldiers gave Cerman snipers a fearsome reputation. They were masters of the craft of war. The sniper's precision killing approximated high modernist art. Not without reason did high modernist art, which arguably originated with the Lost Generation's wartime experience, highlight the importance of impersonality, technical discipline, precision of execution and total control over the medium of representation.

4. Epistemologies of ignorance are forms of unlearning; the complex phenomena of knowledge practices that produce and sustain various forms of ignorance. For the purpose of this article I am limiting myself to those "that take the form of the center's own ignorance of injustice, cruelty, and suffering" (Sullivan and Tuana 1). 
Mainstream Euro-American modernism often celebrated violence and revealed misogynist, anti-Semitic, homophobic, dominationist biases. Ezra Pound idolized Mussolini; Hemingway saw the incarnation of the artist in the figure of the bullfighter. I posit that Fidelis is another quintessential artist of the modernist period.

Endowed with an angelic voice and passionate about poetry, he was forced to "shut down" (Erdrich 2) his senses and do violence to his sensitive nature in the trenches of World War One. Motivated by the need to survive, he became a deadly sniper, "deal[ing] death accurately from his sandbagged and reinforced turret" (5). The mechanical, repetitive nature of this process deadened his consciousness and allowed him to "meticulously oil [...] and clean [...] the workings of his rifle" in between shootings, and continue, day in and day out, "with a raptor's perseverant ease to pluck men from that too shallow rift in the earth" (5). His craft is totally impersonal, divorced from emotions, seemingly effortless, although the appearance of "perseverant ease" results from rigorous discipline and self-control. Fidelis's technical mastery is a death warrant to the eliminable Other on the opposite side of the battlefront. His art is conscienceless. As aptly noticed by Thomas Austenfeld, "[t]he savage butchery of war and the precision butchering of animals, a master craft of long

Captive Minds Normativities and Protests standing, are but two sides of the same coin" (8).

In the Waldvogel family, the arcane skills of butchering have been passed down from father to son for generations. The Waldvogels were not ordinary butchers; they were Metzgemeisters, master butchers:

[...] there was an art to a proper killing. The profession, acquired only through painstaking study and examination form a young age, was one of extraordinary precision and timing. The Metzgemeister's diploma required working knowledge of every spice known to humankind, the arcane preparation of hundreds of varieties of wurst, and the ability to commit one's knife edge to the animal's created bulk and grain with dreamlike intuition. His father, having practiced all his life, hardly seemed to move his hands as the animal fell into increasingly civilized circles and predictable shapes. On a block set before him, its creature- 
liness disappeared and it entered, as Fidelis saw it, a higher and more satisfactory form of being. (8-9)

As demonstrated by the age of genocide, ${ }^{5}$ evil is banal rather than Faustian. It is the law-abiding citizen, the most trustful and trustworthy person (fides means trust, faith) who, having silenced his conscience, becomes a master butcher (of human and non-human animals) totally dedicated to his craft. Only when handling the Other with the indifferent precision of a superior being and with faith (fides) in either his military superiors' orders or man's divinely-ordained right to domination over the animal, will the modern man be able to treat the vilified Other as, respectively, the eliminable enemy and material to shape according to his (the master's) superior vision.

Like his father before him, Fidelis has perfected the skill to "improve" livestock by bringing them from the abyss of chaotic and unpredictable "creatureliness" to a more orderly and superior state, in which all randomness and waste has been eliminated. This is the Western man's most sublime art: the arcane and highly disciplined project of subduing ungovernable matter, making nature profitable, and civilizing it (along with all those who are on the 'nature' side of modern dichotomies). It is safe to argue that, as both sniper and butcher, Fidelis embodies the carnophallogocentric ${ }^{6}$ privileges of Western subjectivity. Meat-eating and killing animals/animalized Others are acts whose aim is, according to Carol Adams, "a sort of desperate performative rebuilding of the carnopallogocentric subject through violence" (36).

In the American context, Fidelis's profession provides another link between human domination over nature and the violence of colonialism. Both projects are directed at the same goal:

5. See, e.g., Samantha Powell, A Problem from Hell: America and the Age of Genocide (Basic Books, 2002).

6. Jacques Derrida introduced the idea of carnophallogocentism in his late essay "Eating Well." According to the philosopher, Western subjectivity is quintessentially virile and masculine (phallo), speaking and self-present (logo), and animal-flesh eating (cf. Adams and Calarco). 
the securing of a continual flow of the spoils of war for the enjoyment of the normative hu/man.

To wit, the violent subjugation and forced dispossession of North America's indigenous people from their tribal territories, as well as the clearing of theGreat Plains of the free roaming buffalo, allowed for the creation of lucrative ranching empires where "domesacrated" animals were raised for profit. Although the notorious Union Stock Yards of Chicago are never mentioned in the Erdrich novel, by the time of Fidelis's arrival in Argus they were already employing 40,000 workers ("The Union Stockyards"). Chicagoan Carl Sandburg called the city "Hog Butcher for the World" (191). Soon the booming animal-industrial complexwas to drive small slaughterhouses (like Fidelis's) out of business. Upton Sinclair's novel The Jungle, depicting animal suffering and immigrant workforce oppression in the Stock Yards, was published in 1914. By then, the meat industry had already established a heavy meat diet as the marker of social standing. For countless immigrants, especially from poverty-stricken regions of Europe, successful assimilation to American culture meant the adoption of meat as their staple diet. Charles Patterson asserts that meat was for them "a rite of passage into the coveted American middle class" (58).

Violence and meat-eating are two sides of the same coin, asserts Carol Adams in an interview with Matthew Calarco;

Captive Minds Normativities and Protests the self-present, speaking, rational, masculine, and flesh-eating human is the essential human who, like Fidelis, kills "with a raptor's perseverant ease" (Erdrich 5).

The raptor is Erdrich's insightful metaphor for humanity, understood, in the words of decolonial philosopher Syl Ko, as "not just homo sapiens but an ideal type of homo sapiens" (73). In her essay "Notes from the Border of the Human-Animal Divide," Ko argues that all inferiorized Others, human and nonhuman alike, are the Fanonian damnés-the wretched of the earth-but they are also "kindred spirits in a fight to depose "the human'" (73). Knowing that "only humans are taken seriously" (74) while those marked by their "less than' status are routinely silenced and invisibilized, Ko advocates a rebellious move, one that runs counter to the much celebrated and hard-won legal inclusion of racialized bodies into the hegemonic 
category of 'the human.' I quote Syl Ko's appeal at some length to illustrate the stakes involved:

Let's use our exclusion and invisibility as a power [...]. Let's use our erasure from this rotten-to-the-core Western notion of humanity to build up a different "new world," one that is not defined in terms of dichotomies or hierarchies or emotional death-but centered on love: one in which we accept ambiguity and difference, grounded in an expansive, limitless "we" [...]. We are realizing that by existing in this strange, liminal space, the space of being not-quite-human, we are forced to reconceive and reject the standard articulation of what speciesism is and how to fight it. In recognizing our strange status explicitly in terms of the grand division that makes all "isms" possible, the human-animal dichotomy, we voluntarily align ourselves with our fellow beings, those who do not belong to homo sapiens, in solidarity as we all somehow continue to thrive despite the crushing weight of the figure "the human." (75)

Delphine failed to align herself with the victims of 'the human.' Bychoosing inclusion in the oppressive category, she compromised her potential to build the world of the You; she failed to act on her extraordinary vision. Syl Ko's words echo bell hooks's realization that the margin has to be freely chosen if it is to become the site of resistance.

A growing number of activists from racial and oppressed minorities are reaching a similar conclusion, the chief target of their criticism being the Eurocentric, normative idea of the human. Critical of Western modernity, with its humanist, liberal discourses, they attempt to decenter whiteness and its supremacist universum by postulating the concept of pluriversality. As defined by Walter Mignolo, pluriversality is the "entanglement of several cosmologies connected today in a power differential. That power differential is the logic of coloniality covered up by the rhetorical narrative of modernity. Modernity is a fiction that carries in it the seed of Western pretense to universality" ("On Pluriversality"). To think pluritopically, though, one needs to dwell in the border, in the entanglement, rather than merely "study" it from the outside. To dwell in the border-or, in hook's terms, in the margin-means choosing it over and against the comforts and securities of the assimilationist center. Decolonial critics point to the necessity of delinking from the compromised epistemologies of the West as a precondition to thinking otherwise. What follows 
is an attempt to look at human-animal relationships differently by challenging the modernist matrix of domination.

OF PIGS AND MEN: TOWARDS THE DISMANTLING OF THE SPECIES BARRIER

Typically, in the racist/speciesist matrix of modernity, the pig, seen as the essence of filth and unruly behavior, has been used to animalize the most 'uncivilized' Other that needs to be disciplined or disposed of altogether. Within Erdrich's novel, Fidelis's sister, simply called Tante-a prim xenophobe, German nationalist, and supporter of Hitler's racist theories-must have used the 'Jewish pig' slogan, which paved the way for the Final Solution. As it turns out, however, the use of pigs for othering was not motivated solely by cultural prejudice or religious taboo. Originally, as argued by Karl Steel in his book How to Make a Human: Animals and Violence in the Middle Ages (2011), pigs were perceived as dangerously similar to humans, therefore threatening to the concept of human exceptionality. The abjection of pigs served the purpose of distinguishing 'ourselves' (humans) from 'them' (animals)-who, as demonstrated by the liminal pigs, were in fact disturbingly like 'us.' "Animal-like and human-like," writes Steel, "reviled for its appetite but useless without it, permitted to live only to be killed, but at the same time also fundamentally ungovernable, even murderous," pigs resisted dichotomization. Steel continues:

Captive Minds Normativities and Protests

7. For a concise treatment of this theme, see especially "Master Species, Master Race" (Patterson 51-108). taire between the rational, 'civilized' masters and the subhuman and nonhuman brutes-the literal and metaphorical pigs. Fidelis's Metzgemeister's diploma is eerily evocative of the supremacist ideology of the master race, which found its consummation in the Jewish Holocaust on the one hand, and the biopolitics of animal agriculture on the other. ${ }^{7}$ The ideology of the master race 
is racist and speciesist at the same time. In both cases, the "less than' human is ultimately devoid of agency, locked in a death camp (the industrial farm for animals) or enslaved in many other ways.

To dismantle the interconnected zones of the human-animal "gulag archipelago" (Wadiwel 24), we need to start from dismantling human sovereignty. As argued by Wadiwel, sovereignty is always declared retroactively, as rationalization or justification of a victory over the Other, whether human or non-human. Sovereignty "is the declaration of non reciprocity; the refusal of alterity through non recognition" (258). In decolonial readings of Hegel's materslave dynamic, the colonial master does not need recognition from the subalter(n)/damné. As demonstrated by Frantz Fanon, the only way for the damné to gain recognition and liberation is through struggle, because only struggle gives the subaltern agency and asserts his/her dignity. In The War Against Animals, Wadiwel posits that animal sovereignty can be understood as "a mode of resistance against human domination" (253). This interpretation is confirmed by ethologists like Evelyn Lawino Abe, or Gay Bradshaw, author of Elephants on the Edge: What Animals Teach Us About Humanity (2009) and founder of trans-species psychology. ${ }^{8}$ Erdrich's Master Butchers offers an example of such a reversal of sovereignty and agency in a scene with a pedigree pig literally rebelling against being slaughtered. By resorting to violence against the butcher, she challenges the perception that farm animals are 'mere' provisions, thus revealing the unnaturalness of the speciesist barrier.

The intelligent price sow is about to be "decreate[d] [...] into rib chops, tenderloin, hams, hocks, pickled feet, fatback, bacon, and sausages" (Erdrich 36). She senses the danger and resists being driven up the chute: she "stood her ground," then charged and bit into Fidelis's knee cap, "shredding [his] trousers and skin to the bone" (37). With the second charge, the pig destroyed "what was left of his knee with another lurching bite. She then repaired to her corner, red-eyed, bleary with hatred, sobbing" (37). From the space

8. Sarat Cooling provides a useful list of scholars who write about animal resistance ("Animal Agency, Resistance and Escape" in Critical Animal Studies: Towards Trans-species Social Justice, edited by Atsuko Matsuoka and John Sorenson, Rowman and Littlefield International, 2018, pp. 21-44). 
of ethical suspension to which she has been relegated by Fidelisthe archetypal modern hu/man, Erdrich's militant sow asserts agency by struggling against the oppressor, rather than passively wait to be killed. She challenges the idea of human supremacy naturalized by species war. The uneven battle between Fidelis (armed and abetted by his son) and the (unarmed) sow cannot end otherwise than in the animal's defeat. Had they confronted each other on equal terms, however, the result could have been diametrically different.

Despite his victory, Fidelis's world has been shattered by an unwanted intimation of kinship with the slaughtered animal. He is overwhelmed by grief and an irrational desire to lie down in mud and cry-"and was all the more horrified to realize that he wept for the sow. How could that be?" Fidelis is bewildered: "He had killed people. He had seen them die. His best friend had died beside him. No tears. What sort of man was he to weep, now, for a pig?" (38). Furious with himself for this 'unmanly' weakness, he forces himself to ignore his wound and oversees the smallest details of processing the meat. As if his powerful will could bend reality, annul the unwelcome revelation, and return him to the safety of tested truths. Denying his own animality, he denies the reality of the body and its senses. Fidelis-the modern human-lives in denial, a denial that originates with his formative wartime

Captive Minds Normativities and Protests experience, this symbolic rite of passage to modern manhood for members of his generation.

Having returned from the Great War with an undiagnosed Posttraumatic Stress Disorder, Fidelis realized he must keep his senses shut. "Memories would creep up on him," he thought to himself, "emotions sabotage his thinking brain. To come alive after dying to himself was dangerous. There was far too much to feel, so he must seek, he thought, only shallow sensations" (2). Significantly, his protective cover is pierced twice and both times he is caught unawares by emotions too primal to be kept in check by the supposedly rational, autonomous self. Weeping for the pig comes years after the first awakening experience: his unexpected love for Eva Kalb, the fiancé of his fallen friend. Upon delivering 
the news of Johannes's death, "Fidelis saw her [Eva], for one moment, in the state of a naked being accepting pain" (4).

In traumatic conditions, the veneer of socially constructed difference between humans and animals evaporates; the human, reduced to biology, is revealed as constituted by the animal Other we are encouraged to renounce in the process of self-constitution. Deadened by the terrifying news, Eva Kalb-'Kalb' being the German word for 'calf'-is like an animal brought to the slaughter; she is zoe, a naked being, an animal stunted before being killed. ${ }^{9}$ Having "slumped toward him [Fidelis], hands clasped, face calm" (4), she anticipates the long line of farm animals (with whom she shares her maiden name) brought to Fidelis every week for slaughter. And the butcher will be there every week "to carry out death's chores" (378), like he was there for the Kalb in Eva's maiden name, which had to be killed into Waldvogel. Having symbolically surrendered to modern masculinity, Eva becomes a "proper" woman: a mother (Eve is the biblical name of the mother of humankind), wife, and her husband's accomplice in the war against animals. Curiously, the abjected animality is still preserved in her married surname. "Forestbird," as Americans pointed out to the butcher, "was an oddly gentle name for one whose profession was based in slaughter" (8).

In the trenches of war Fidelis had a premonition of the underlying similarity, even kinship between humans and animals. But at that point in life he was a bundle of instincts and unable to understand this. Later in life, he will be too bent on proving his manly worth and 'making it' in the American melting pot to allow himself the luxury of philosophical deliberations. An awareness of the underlying identity between himself and the animals he has been slaughtering most of his life will finally resurface at the hour of his death: "He was on his hands and knees, kneeling there on the floor like an animal. This was the way the animals suddenly collapsed, but, he thought, wearily, this is an arrival gate, not a killing chute" (378). Returning to the USA, this modern man who till the very

9. It would be interesting to apply the feminist lens, or, even more intriguingly, Carol Adam's theory of the sexual politics of meat, to Eva's symbolic death in the arms of her husband-to-be. Tempting as it may be, this exercise would require more space than is available to the author of this article. 
end "would not accept the news that he was ill," who "ignored his body, despised its needs, kept his old habits as though they would bring back his power" (377), collapses to the floor. Now the butcher looks at the world from the vantage point of an animal he would routinely slaughter, wondering "[w]ho was there to do the same for him?" (378).

\section{BY WAY OF A CONCLUSION}

David Nibert's concept of domesacration, foregrounding the violence of enslaving animals for human profit, captures the founding moment of species war. As "spoils of war," domesacrated animals become objects devoid of the agency they used to enjoy in traditional, pre-colonial worldviews. The institution of animal slavery breaks with the early form of communal multispecies society based on kinship (Serpell; Nibert).

Step-And-A-Half's ancestors, the indigenous peoples of the Northeastern Woodlands, were nomadic hunters and gatherers who treated animals as their equals. The notion of human sovereignty was and still is inimical to traditional worldviews that go back to Paleolithic times. On the other hand, the driving idea of modernity, the worldview imported by European colonizers, was connected to human exceptionality and the supposedly divine mandate to 'subdue the earth.' Rather than asking an animal's permission to give its flesh as food for needy humans and then

Captive Minds Normativities and Protests offering thanks for the gift of animal life-as the indigenous nomads would do-settlers showed no respect for native animals' life and they slaughtered livestock by the thousands. While the indigenous inhabitants of the Dakotas had lived in harmony and mutuality with the land and everything on it, the European newcomers brought a maimed idea of community, from which all were excluded save for Westernized humans.

For scholars drawing inspiration from traditional and indigenous worldviews, the idea of human dominionism is the essence of colonization. Amba J. Sepie from the University of Canterbury, Christchurch, argues: "we have been collectively colonized, over a very long time, out of this integrated and intuitive relationship with other humans, other species, and the world around us" (10). Understanding colonization as "an extended process of denying 
relationships" (Dwayne Donald, qtd. in Sepie 10), Sepie warns against a shallow, ethnographic framing of the process of epistemic decolonization. "The objective of decolonization, as a global project," she writes, "is to reassess our collective, diverse, cosmological assumptions with respect to all our relationships, in a manner that allows for the reconfiguring of the dominant perceptions of humanity, and recalibrates human relations with otherness of all kinds" (25).

Native American Viola Cordova explains that most indigenous peoples believe they are "part of the Earth" (How It Is 151) and that those who separate themselves from the never-ending web of kinship with all existence are not really humans but "ghostly beings residing in decadent bodies on inanimate and alien ground" (How It is 213). To be fully human, therefore, we need to be in a relationship with the nonhuman Other, to treat animals and other earth beings as a Thou. For us, dwellers in late modernity, this implies liberating ourselves from the unexamined assumptions and presumptions we live by. Thinking differently is the first step towards living differently.

I want to close this article by quoting the words of a long-time advocate for animal and nature rights, the Chickasaw writer and activist Linda Hogan. It is fitting that the last words should belong to indigenous people themselves. In her upcoming book, The Radiant Lives with Animals, Hogan writes:

A word for animal Nan okcha means all alive. It means more than only that which is animated. Embedded in the language, it says that the animals have lives and being and are sentient, as is now known and related by Western science. Animals, like plants are a significant part of a whole. They have relationship and connection with other lives and an animate world that is the world at large. In the traditional world view, we have an awe of them and an obligation to keep all alive. That is a part of our human purpose here. 
WORKS CITED

Adams, Carol and Matthew Calarco. "Derrida and the Sexual Politics of Meat." Meat Culture, edited by Annie Potts. Brill, 2017, pp. 31-52.

Agamben, Giorgio. The Open. Translated by Kevin Attell, Stanford UP, 2004.

Ausenfeld, Thomas. "Cerman Politics and Culture in Louise Erdrich's The Master Butcher's Singing Club. Great Plains Quarterly, no. 26, 2006, pp. 3-11.

Cooling, Sarat. "Animal Agency, Resistance and Escape." Critical Animal Studies: Towards Trans-Species Social Justice, edited by Atsuko Matsuoka and John Sorenson. Rowman and Littlefield International, 2018, pp. 21-44.

Dekha, Maneesha. "The Subhuman as a Cultural Agent of Violence." Women of Color in Critical Animal Studies, special issue of Journal of Critical Animal Studies, vol. 8, no. 3, 2010, pp. 28-51.

Erdrich, Louise. The Master Butchers Singing Club. Harper Collins, 2003.

Grosfoguel, Ramon. "Decolonizing Political Economy and Postcolonial Studies: Transmodernity, Border thinking, and Global Coloniality." Humandee: Human Management and Development. July 4, 2008, http://www.humandee.org/. Accessed 25 March, 2019.

Captive Minds Normativities and Protests

Hogan, Linda. "Dawn for All Time." The Radiant Life with Animals (upcoming), https://www.academia.edu/31773069/E_3_ essays_The_Radiant_Life_with_Animals. Accessed 25 April, 2019.

hooks, bell. "Choosing the Margin as a Space of Radical Openness." Yearnings, Race, Gender and Cultural Politics. South End P, 1989, pp.203-209.

How It Is: Native American Philosophy of V.F Cordova, edited by Kathleen Moore, Kurt Peters, Ted Jojola, and Amber Lacy, with a foreword by Linda Hogan. U of Arizona P, 2007.

Ko, Syl. "Notes from the Border of the Human-Animal Divide." Aphroism: Essays on Pop Culture, Feminism, and Black Veganism from Two Sisters by Aph and Syl Ko. Lantern Books, 2017, pp. $70-75$. 
Kochi, Tarik. "Species War: Law, Violence and Animals," Law, Culture And the Humanities, vol. 5, 2009, pp. 353-369.

Maldonado-Torres, Nelson. Against War: Views from the Underside of Modernity. Duke UP, 2008.

Mayblin, Lucy. "Modernity/Coloniality." Global Social Theory. https:// globalsocialtheory.org/concepts/colonialitymodernity/. Accessed 20 May, 2019.

Mignolo, Walter. "Epistemic Disobedience, Independent Thought and De-Colonial Freedom,"waltermignolo.com/wp-content/ uploads/2013/03/epistemicdisobedience-2.pdf. Accessed 23 March, 2019.

------. "On Pluriversality. waltermignolo.com/on-pluriversality. Accessed 23 March, 2019.

Nibert, David A. Animal Oppression and Human Violence: Domesacration, Capitalism, and Clobal Conflict, Columbia UP, 2013.

Parenti, Michael. "Lies, Wars, and Empire," lecture, May 12, 2007, Antioch University, Seattle, Wash, https://www.youtube. com/watch?v=CZTrY3TQpzw. Accessed 8 March, 2019.

Patterson, Charles. Eternal Treblinka: Our Treatment of Animals and the Holocaust. Lantern Books, 2002.

Rowe, John Carlos. Afterlives of Modernism: Liberalism, Transnationalism, and Political Critique. Dartmouth College Press, 2011.

Sandburg, Carl. "Chicago." Poetry: A Magazine of Verse, March 1914, vol. 3, no. 6, pp. 191-192.

Sepie, Amba J. "More than Stories, More than Myths: Animal/Human/ Nature(s) in Traditional Ecological Worldviews. Humanities, vol. 6, no. 4, 2017.

Serpell, James. In the Company of Animals: A Study of Human-Animal Relationships. (1986). Cambridge UP, 1996.

"Snipers in the First World War." Spartacus Educational. www.spartacus-educational.com. Accessed 26 March, 2019.

Steel, Karl. How to Make a Human: Animals and Violence in the Middle Ages. Ohio State UP, 2011.

Sullivan, Shannon and Nancy Tuana, editors. Race and Epistemologies of Ignorance. State U of New York P, 2007. 
Captive Minds Normativities and Protests

욤

"The Union Stockyards." Chicago Stories. WTTW. https://interactive. wttw.com/a/chicago-stories-union-stockyards. Accessed 26 March, 2019.

Wadiwel, Dinesh. The War Against Animals. Brill, 2015. 